\title{
The Marine Food Chain in Relation to Biodiversity
}

\author{
Andrew R.G. Price \\ Ecology and Epidemiology Group, Department of Biological Sciences \\ University of Warwick, Coventry CV4 7AL, UK
}

Received June 13, 2001; Revised September 10, 2001; Accepted September 10, 2001; Published October 19, 2001

Biodiversity provides "raw materials" for the food chain and seafood production, and also influences the capacity of ecosystems to perform these and other services. Harvested marine seafood species now exceed 100 million $\mathrm{t}^{-1}$ and provide about $6 \%$ of all protein and $17 \%$ of animal protein consumed by humans. These resources include representatives from about nine biologically diverse groups of plants and animals. Fish account for most of the world's marine catches, of which only 40 species are taken in abundance. Highest primary productivity and the richest fisheries are found within Exclusive Economic Zones (EEZ). This narrow strip (200 nautical mile $/ 370 \mathrm{~km}$ wide) is not only the site of coastal "food factories" but also the area associated with heaviest perturbation to the marine environment.

Structural redundancy is evident in marine ecosystems, in that many species are interchangeable in the way they characterise assemblage composition. While there is probably functional redundancy within groups, the effects of species loss on ecosystem performance cannot be easily predicted. In particular, the degree to which biodiversity per se is needed for ecosystem services, including seafood/fishery production, is poorly understood.

Many human activities, including unsustainable fishing and mariculture, lead to erosion of marine biodiversity. This can undermine the biophysical cornerstones of fisheries and have other undesirable environmental side effects. Of direct concern are "species effects", in particular the removal of target and non-target fishery species, as well as conservationally important fauna. Equally disrupting but less immediate are "ecosystem effects", such as fishing down the food web, following a shift from harvested species of high to low trophic level. Physical and biological disturbances from trawl nets and dynamite fishing on coral reefs can also severely impact ecosystem structure and function. "Broadscale" biological and social effects brought about by fishing carry even more far-reaching consequences. For example, fishing itself can change the age at which sexual maturity is reached, thus affecting the reproductive status of the stock. Hence, fishing may be regarded as a mediator of evolution. Social impacts include conflicts over fish prices and policies arising from heavy fishing and inadequate institutional structures.

Measures to increase the sustainability of catches and of biodiversity need to be much more tightly coupled. Promising approaches include use of bio-economic indicators and fully protected marine areas. High- and local-level governance options are also examined. Use of expert systems incorporating "fuzzy logic" are providing useful environmental insights in the ASEAN countries and other parts of the world, and have applications in fishery management and biodiversity conservation. 
KEY WORDS: seafood, fishing, ecosystems, environmental impacts, governance

DOMAINS: global systems, marine systems, ecosystems and communities, environmental sciences, environmental management, computational biology

\section{INTRODUCTION}

Marine food chains leading to seafood species are among the many goods and services generated by marine ecosystems. Their utilisation has been a characteristic of human societies since earliest times. In the Red Sea, for example, this began during the Middle Palaeolithic[1], i.e., at least 100,000 years ago. Initially, relatively few species were harvested, and impacts on stocks and marine biodiversity would have been modest compared with the effects of fishing today. However, population failures of exploited species are not just recent phenomena. One example is green turtles in the Cayman Islands, the fishery for which crashed the $18^{\text {th }}$ century and was gone by 1800 [2]. During the same century Steller's sea cow was hunted to extinction.

The $20^{\text {th }}$ century, in particular, has seen the greatest change. Expanding populations and markets, coupled with improved fishing technologies, have greatly increased the range of exploitable and exploited seafood species. Resource exploitation now directly targets more components of marine biodiversity than ever before. But it is also evident that marine biodiversity - the structural and functional cornerstones of marine food chains - is being eroded by a multitude of activities. Ironically, these include fishing itself and mariculture.

The overall objective of this paper is to examine associations between marine food chains, human activities that exploit them, and biodiversity. Two fundamental questions are 1) to what extent are seafood production and overall marine biodiversity of an ecosystem interdependent, and 2) how seriously are fishing and aquaculture, as human impacts, eroding biodiversity?

Following the introduction, the paper reviews the direct value of biodiversity, as "raw materials" for the food chain and seafood species harvested by humans. It also examines links between harvested species and overall biodiveristy of the marine ecosystem. This is followed by assessment of the impacts of fishing and related activities on marine biodiversity and the environment. The paper concludes with examination of wider governance implication of the marine food chain and its interconnections with biodiversity, considering both technical/scientific and legal aspects.

\section{THE FOOD CHAIN AS AN INTEGRAL COMPONENT OF BIODIVERSITY}

\section{Provision of Seafood Species}

Seafood and other marine species can be classified according to habitat (e.g., demersal/pelagic species) and, linked to this, fishing method (demersal trawling, drift net and purse-seining, lines, traps and cages, or explosives). Marine resources can also be classified by mode of feeding (e.g., herbivore, planktivore, or piscivore) or behaviour (e.g., anadromous or catadramous [Table 1]). Taxonomic grouping is another obvious division, and one clearly relevant to this paper. 
TABLE 1

World Catches $\left(\mathrm{mt} \times 10^{6}\right)$ of Marine Living Resources by Species Groups*

\begin{tabular}{|c|c|c|c|c|c|c|c|}
\hline Species Group & 1990 & 1991 & 1992 & 1993 & 1994 & 1995 & 1996 \\
\hline \multicolumn{8}{|l|}{ FISH } \\
\hline Flounders, halibuts, soles & 1.21 & 1.08 & 1.16 & 1.09 & 0.98 & 0.91 & 0.92 \\
\hline Cods, hakes, haddocks & 11.58 & 10.24 & 10.43 & 9.92 & 9.64 & 10.61 & 10.71 \\
\hline Redfishes, basses, congers & 5.73 & 5.93 & 5.96 & 5.69 & 6.31 & 6.85 & 6.61 \\
\hline Jacks, mullets, sauries & 9.59 & 10.16 & 10.36 & 9.96 & 9.88 & 10.84 & 11.14 \\
\hline Herrings, sardines, anchovies & 22.32 & 21.72 & 21.20 & 21.89 & 25.84 & 21.97 & 22.32 \\
\hline Tunas, bonitos, billfishes & 4.40 & 4.59 & 4.51 & 4.55 & 4.62 & 4.71 & 4.58 \\
\hline Mackerels, snoeks, cutlassfishes & 3.55 & 3.47 & 3.45 & 4.01 & 4.51 & 4.69 & 5.14 \\
\hline Sharks, rays, chimaeras & 0.69 & 0.71 & 0.73 & 0.74 & 0.75 & 0.76 & 0.76 \\
\hline Misc. marine fishes & 10.04 & 9.91 & 10.66 & 11.13 & 11.03 & 11.36 & 11.99 \\
\hline \multicolumn{8}{|l|}{ CRUSTACEANS } \\
\hline Sea spiders, crabs & 0.87 & 1.00 & 1.04 & 1.03 & 1.21 & 1.17 & 1.22 \\
\hline Lobsters, spiny rock lobsters & 0.21 & 0.22 & 0.21 & 0.21 & 0.21 & 0.22 & 0.21 \\
\hline Squat lobsters & $<0.1$ & $<0.1$ & $<0.1$ & $<0.1$ & $<0.1$ & 0.01 & 0.01 \\
\hline Shrimps, prawns & 1.97 & 2.02 & 2.09 & 2.09 & 2.25 & 2.28 & 2.47 \\
\hline Krill, planktonic crustaceans & 0.37 & 0.36 & 0.31 & 0.09 & 0.08 & 0.12 & 0.10 \\
\hline Misc. marine crustaceans & 0.46 & 0.58 & 0.62 & 0.83 & 0.90 & 1.03 & 1.09 \\
\hline \multicolumn{8}{|l|}{ MOLLUSCS } \\
\hline Abalones, winkles, conches & 0.08 & 0.08 & 0.08 & 0.09 & 0.10 & 0.10 & 0.10 \\
\hline Oysters & 0.13 & 0.11 & 0.13 & 0.13 & 0.13 & 0.17 & 0.16 \\
\hline Mussels & 0.26 & 0.25 & 0.28 & 0.27 & 0.28 & 0.24 & 0.20 \\
\hline Scallops, pectens & 0.53 & 0.47 & 0.51 & 0.48 & 0.60 & 0.50 & 0.46 \\
\hline Clams, cockles, arkshells & 1.04 & 0.97 & 1.01 & 1.01 & 0.94 & 0.96 & 0.93 \\
\hline Squids, cuttlefish, octopuses & 2.26 & 2.57 & 2.74 & 2.72 & 2.77 & 2.86 & 3.04 \\
\hline Misc. marine molluscs & 0.66 & 0.67 & 0.90 & 1.13 & 1.22 & 1.41 & 1.05 \\
\hline \multicolumn{8}{|l|}{ MARINE MAMMALS $\left(\right.$ no. $\left.\times 10^{3}\right)$} \\
\hline Blue whales, fin whales & 0.64 & 0.66 & 0.55 & 0.73 & 0.86 & 0.98 & 1.21 \\
\hline Sperm whales, pilot whales & 114 & 72 & 40 & 42 & 38 & 22 & 22 \\
\hline Eared seals, hair seals, walruses & 184 & 201 & 216 & 160 & 220 & 162 & 369 \\
\hline Misc. aquatic mammals & 2.09 & 1.64 & 1.26 & 1.55 & 1.61 & 1.26 & 1.75 \\
\hline \multicolumn{8}{|l|}{ REPTILES } \\
\hline Turtles & $<0.1$ & $<0.1$ & $<0.1$ & $<0.1$ & $<0.1$ & $<0.1$ & $<0.1$ \\
\hline \multicolumn{8}{|l|}{ ASCIDIANS } \\
\hline Sea-squirts, other tunicates & $<0.1$ & $<0.1$ & $<0.1$ & $<0.1$ & $<0.1$ & $<0.1$ & 0.21 \\
\hline \multicolumn{8}{|l|}{ MERESTOMATA } \\
\hline $\begin{array}{l}\text { Horseshoe crabs, other } \\
\text { arachnoids }\end{array}$ & $<0.1$ & $<0.1$ & $<0.1$ & $<0.1$ & $<0.1$ & $<0.1$ & $<0.1$ \\
\hline \multicolumn{8}{|l|}{ ECHINODERMS } \\
\hline Sea urchins, other echinoderms & 0.95 & 0.10 & 0.10 & 0.11 & 0.12 & 0.13 & 0.12 \\
\hline Misc. aquatic invertebrates & 0.15 & 0.25 & 0.49 & 0.28 & 0.31 & 0.43 & 0.52 \\
\hline \multicolumn{8}{|l|}{ ALGAE } \\
\hline $\begin{array}{l}\text { Seaweed, other aquatic plant } \\
\text { production }^{\mathrm{a}}\end{array}$ & 1.18 & 1.05 & 1.05 & 0.98 & 1.05 & 1.16 & 1.12 \\
\hline
\end{tabular}

*Salmon, eels and other fish spending part of their life cycle in freshwater are not included in the table. These include anadramous fish (e.g., salmon, sturgeon, shad, smelt, sea lampreys) which breed in freshwater, whereas adults spend most of their lives at sea; and catadramous fish (e.g., American and European eels), which breed in the sea but spend the majority of adult life in freshwater.

${ }^{a}$ Some used for human consumption, but mostly for other products.

Data taken from Reference 56. 
Harvested marine fish and other living marine resources fall into nine principal taxonomic/species groups, based on a global compilation of catch records (Table 1). These include biologically diverse representatives of plants and animals (invertebrates and vertebrates) which include: (1) algae/aquatic plants; (2) crustaceans; (3) molluscs; (4) reptiles; (5) merestomata (horseshoe crabs and other arachnoids); (6) echinoderms (sea urchins and sea cucumbers); (7) ascidians (sea squirts); (8) fish; and (9) marine mammals.

Fish are the dominant group within the marine food chain in terms of global catches (Table 1). Only forty of the world's $>20,000$ fish species[3] are taken in abundance. Many more species are taken in smaller quantities, for example by multi-species tropical artisanal fisheries. Six groups (cod, herring, jack, redfish, mackerel, and tuna) account for nearly two thirds of the annual commercial marine fish catch. This is not unlike the pattern for terrestrial food production, in which only 15 plant and 8 animal species supply $90 \%$ of the "global larder", with just four crops (wheat, rice, corn, and potato) accounting for more food production than all other crops combined[4].

More than 100 million tonnes of fish are caught from the sea annually[5]. Direct consumption of fish and shellfish worldwide provides about $6 \%$ of all protein and $17 \%$ of animal protein consumed by humans; a further $5 \%$ of human protein consumption derives indirectly from livestock fed with fish meal[6]. Of the total world population of $>6$ billion, an estimated 1 billion, principally from Africa and Southeast Asia, rely on fish and shellfish as their staple protein[6]. The ocean accounts for more than $80 \%$ of the annual catch, of which $99 \%$ is taken from coastal waters. These are by far the most productive parts of the ocean and include estuaries, mangroves, marshes, seagrasses, coral reefs, and areas of upwelling. Principally by the action of offshore winds, cold, nutrient-rich water comes to the surface from below to replace the warmer, nutrientdepleted water of surface waters. These coastal "food factories" lie within $370 \mathrm{~km}$ (200 nautical miles) of the coastal, i.e., within coastal states' Exclusive Economic Zones (EEZ). Yet it is this same narrow coastal strip which is subject to the heaviest pressures in the marine environment[7].

Global aquaculture now accounts for $25 \%$ of fish consumption and has doubled in weight and output between 1986 and 1996[8]. Farmed shrimp alone have an annual value of more than $\$ 6$ billion.

\section{Biodiversity and Ecosystem Integrity in Relation to the Food Chain}

The extent to which fish and other seafood production depend on biodiversity of the ecosystem is a critical but poorly understood issue. Marine macrofauna (retained on 200- to 500- $\mu \mathrm{m}$ sieves) of marine sediments are the most extensive faunal assemblage on earth, playing critical functional roles in biogeochemical processes[9]. They are particularly important in secondary production, both as a direct food source (e.g., clams) and as major food sources for bottom-feeding (demersal) species that are commercially fished[10]. Many species have been shown to be interchangeable in the way they characterise assemblage composition, suggesting structural redundancy to be remarkably high[11].

Functional redundancy, however, is more complex. Certainly, complete loss (or, in some cases, addition) of particular macrofaunal species, keystone predators or a trophic group can substantially disrupt ecosystem functioning[9,12]. In San Francisco Bay, invasion of a suspension-feeding bivalve species (Potamocorbula amurensis) resulted in reduced water column primary production[13]. A contrasting example is the invasion of the Asiatic suspension-feeding clam, Corbicula fluminea, in the Potomac River Estuary (Washington, D.C.), which led to a decrease in water turbidity but increase in submerged macrophytes, bird, and fish populations[14]. While there is probably appreciable functional redundancy within groups, it is generally not possible to predict the effects of species loss on ecosystem performance[15]. Often 
several species seem to be occupying the same trophic role, suggesting that biodiversity loss might be inconsequential in many cases. However, it would be premature to generalise between redundancy for one specific ecological role and another and to extend this generalization to ecosystem services overall[9]. A study of seagrasses reveals strong positive association between biodiversity and marine ecosystem functions, together with the services yielded to humanity. In general, and in response to the first fundamental question raised, the degree to which biodiversity per se is needed for ecosystem services[9,12,15] and seafood production is still unclear. For example, following an ecosystem perturbation, fish harvests might decline directly from the impact(s), or indirectly from biodiversity reduction caused by the impact(s). A further issue is that biodiversity is a multi-faceted concept and measure[16,17], and a particular impact can even result in an increase in biodiversity, according to some measures (Shannon Wiener, Simpson's index), yet a decrease, according to others (taxonomic distinctness[18]). Because of the many uncertainties, a precautionary approach is advocated, with efforts directed at minimizing biodiversity loss from fishing, pollution and habitat degradation, as well as global warming[15].

\section{IMPACTS OF FOOD CHAIN HARVESTING ON BIODIVERSITY}

\section{Fishing}

Many components of biodiversity contribute to global catches of seafood and other living marine resources, as shown above. Some fisheries appear to be sustainable, such as the Loligo squid fishery in Falklands waters[19], but many are not. This section shows that fishing itself can lead to erosion of biodiversity, undermine biophysical cornerstones of fisheries and have other undesirable environmental side effects (Table 2). Fishery species face particularly acute problems when critical life-cycle phases are disrupted by heavy fishing and/or other environmental pressures, particularly in spawning areas and nursery areas[20,21,22].

Capture fisheries are currently in global crisis and have created many problems. In place of renewable stocks for society's future use, many of the world's fisheries have left behind a litany of disasters. These range from stock collapses, reduction of higher order animals such as cetaceans[23], environmental impacts, and unsustainability to social conflict, dislocation, and economic downturns.

Reduced stock size of target fishery species is the effect of fishing generally acknowledged and best understood. Less obvious, indirect impacts have also affected biodiversity. These include increased mortality of non-target species, such as trash fish, and conservationally important species captured inadvertently as by-catch[23]. These impacts are referred to in Table 2 as "Species Effects". "Ecosystem effects" of fishing go far beyond just species and are equally problematic. Acute examples include extensive biophysical damage to coral reefs and the seabed caused by trawl nets and dynamite fishing on coral reefs. A more subtle but no less significant disturbance is "fishing down marine food webs"[24]. This results in loss of higher trophic-level species from fishing, causing destabilization of food webs and eventually leading to loss of productivity. However, other factors may also be at play, such as altered harvesting patterns (e.g., of short-lived invertebrates later in the time series), which is consistent with a move downwards in trophic-level targeting[25].

"Broadscale" biological and social effects brought about by fishing carry even more farreaching consequences (Table 2). For example, fishing itself can change the age at which sexual maturity is reached, thus affecting the reproductive status of the stock. Hence, fishing may be regarded as a mediator of evolution. Further details of fisheries effects on ecosystems and biodiversity are given in recent reviews[26,27]. Economic and sociopolitical effects of fishing are now global in extent, highly complex, and not always predictable. These are seldom adequately integrated with biological and technical aspects of fisheries[28,29,30]. 
TABLE 2

Direct and Indirect Effects of Fishing on Species, Ecosystems, and Biodiversity Fishing Effect

Impact(s) or Consequence(s)

References

SPECIES EFFECTS

Removal of target fish species

By-catch (1): removal of nontarget fish species (e.g., undersized marketable species, species not currently marketable, or target species) By-catch (2): removal of conservationally important fauna (e.g., marine mammals, turtles, and birds)

\section{ECOSYSTEM EFFECTS}

Fishing down marine food webs

Food web competition

Other biological effects on ecosystem structure

Physical effects on ecosystems

$>70 \%$ of world's commercially important marine fish stocks fully fished, over-exploited, depleted, or slowly recovering; increased likelihood of species loss or extinction caused by overexploitation

By-catch, or discards, range from 17.9 to 39.5 million $\mathrm{t}^{-1}$ or an average of 27 million $\mathrm{t}^{-1}$; this replacement of high value fish by "trash" fish represents enormous wastage of fishery resources

Capture of porpoises in gill nets and of turtles in trawl nets not fitted with turtle exclusion devices (TEDI); incidental mortality of species long-lived and with low reproductive rates ( $K$ selected species) is a major conservation problem

Stagnating or declining catches, i.e., unsustainability of fisheries, following shift from landings of high trophic-level, long-lived species ( $K$-selected species) to low trophic-level, short-lived species ( $r$-selected species)

$25-34 \%$ of primary production in shelf waters (which provide $95 \%$ of catches) is harvested, bringing humanity into competition for primary productivity with other apex predators (e.g., seabirds, marine mammals) Reduced species diversity and local extinctions of both fishery and other e.g., keystone species; phase shifts from removal of fish predators of urchins, reducing reef accretion, and possibly increasing erosion; interactions between fishing and other agents to impair ecosystem recovery following hurricanes and other natural disasters

Physical (and biological) ecosystem disturbances from trawl nets and dynamite fishing

$\underline{42}, \underline{43}, \underline{44}$

$\underline{45}, \underline{46}$

$\underline{47}$

$\underline{24}$

Trend toward removal of larger sized fish, slower growth, and decline in age and/or size at sexual maturity; changes result from compensatory responses as well as genetic effects

BROADSCALE EFFECTS

Evolutionary effects

Genetic effects

Some evidence of reduced genetic diversity, e.g., orange roughy, virgin stocks of which have been harvested beyond

their maximum sustainable yield

Economic and political effects

Conflicts over fish prices, financial insecurity, and political dislocation, arising from combination of heavy fishing of shared stocks and inadequate institutional management structures

\section{Mariculture}

Like fishing, aquaculture often results in negative environmental impacts[8], including the direct or indirect loss of biodiversity. Common problems include: chemical and biological pollution (e.g., nutrients) from shrimp and other farms; misuse of chemicals, such as antibiotics; introduction of exotic species and diseases, including passing through food chain of Escherichia coli, Norwalk-type viral diseases, shigellosis, and cholera, as well as their spread from one ecosystem to another[31,32]; degradation of mangroves and other natural ecosystems; abandonment of aquaculture ponds, which can then be unsuitable for other activities, such as agriculture; and use of large amounts of fish oil and fishmeal taken from wild caught fish for farmed carnivorous species. These and other problems have been addressed in a recent review[8]. Insuffiently prominent in many reviews and critiques, however, is the fact that there are now many examples of good (sustainable) aquaculture practice[33,34]. 
Hence, in response to the second fundamental questions raised, it is evident that mariculture and fisheries can be sustainable. However, there are many instances of both practices eroding biodiversity and undermining ecosystem functions, aside from the obvious effects of stock depletion by capture fisheries.

\section{WIDER GOVERNANCE IMPLICATIONS}

Measures to increase the sustainability of catches and of biodiversity needs to be much more tightly coupled. One approach is assessment of fishery performance through use of bio-economic indicators, which requires recognition of the uncertainty of marine systems[35]. There is also compelling evidence that use of fully protected marine areas can optimise fishery yields and, at the same time, conserve biodiversity in the face of uncertainty[36,37].

One current, high-level initiative is examining possible cooperation between Regional Seas conventions of the United Nations Environment Programme (UNEP) and regional fishery bodies in the field of ecosystem-based management of fisheries[38]. This should be beneficial to both fisheries and biodiversity. At the local level, customary marine approaches can act in a similar way, despite dilution by western influence during recent decades[39]. In the Philippines, the value of mangroves to fisheries and coastal conservation has been long recognised. Problems arose in the 1980s, however, when local people could obtain coastal tenure only if mangroves were cleared for shrimp mariculture sites. This was done, to satisfy government policy requirements but against their better judgement, leading to an array of problems for fisheries, mariculture, and coastal biodiversity. Another critical issue which needs to be addressed further, in view of the considerable local and global consequences, is the extent to which mariculture products should be for "fish or finance".

Use of expert systems incorporating "fuzzy logic" are providing useful environmental insights in the ASEAN countries and other parts of the world[40,41,42], and have applications in fishery management and biodiversity conservation. Fuzzy logic operates using a system of generic rules that involves trade-offs between data resolution and computing speed and also has other benefits.

\section{ACKNOWLEDGEMENTS}

The suggestions of J. McGlade, C. Roberts, and C. Sheppard are acknowledged with thanks.

This paper is based on input to project, "Biodiversity: Its Importance to Human Health" supported by Center for Health and the Global Environment, Harvard University, the World Health Organization, and the UN Environment Programme. This and other documents will form the basis of a report to be published and presented at a Special Session of the UN General Assembly, June 2002. Its ultimate aim is to provide input to UN Convention on Biological Diversity and to the major international effort, "The Millennium Ecosystem Assessment".

\section{REFERENCES}

1. Horton, M. (1987) The human settlement of the Red Sea. In Key Environments: Red Sea. Edwards, A.J. and Head, S.M., Eds. Pergamon Press, Oxford. pp. 339-362.

2. Jackson, J.B.C. (1997) Reefs since Columbus. Coral Reefs 15(Suppl. 23-S32).

3. Lalli, C.M. and Parsons, T.R. (1993) Biological Oceanography: An Introduction. Pergamon Press, Oxford.

4. Miller, G.T., Jr. (1998) Living in the Environment, Wadsworth Publ. Co., Belmont, CA.

5. Shepherd, J. (1998) Sustainable exploitation - lessons from the management of fisheries. In Depth, Southampton Oceanography Centre 4, 1-2. 
6. Miller, G.T.Jr. (1996) Living in the Environment, Wadsworth Publ. Co., Belmont, CA

7. Price, A.R.G., Edwards, A., Burbridge, P., and Brown, B.E. (1993) Coasts. Environment and Development Briefs. 6, UNESCO, Paris, 16 p.

8. Naylor, R.L. Goldberg, R.J., Mooney, H., Beveridge, M., Clay, J., Folke, C., Kautsky, N., Lubchenko, J., Primavera, J., and Williams, M. (1998) Nature's subsidies to shrimp and salmon farming. Science 282, 883-884.

9. Snelgrove, P.V.R. (1998) The biodiversity of macrofaunal organisms in marine sediments. Biod. Conserv. 7, 1123-1132.

10. Carlson, J.K., Randall, T.A., and Mroczka, M.E. (1997) Feeding habits of winter flounder (Pleuronectes americanus) in a habitat exposed to anthropogenic disturbance. J. Northwest Atl. Fish. Sci. 21, 65-73.

11. Clarke, K.R. and Warwick, R.M. (1998) Quantifying structural redundancy in ecological communities. Oecologia 113, 278-289.

12. Austen, M.C., Lambshead, P.J.D., Hutchings, P.A., Boucher, G., Heip, C., King, G., Koike, I., Smith, C.R., and Snelgrove, P. Do biodiversity links above and below the marine sediment-water interface affect stability? Biodiv. Conserv. in press.

13. Alpine, A. and Cloern, E. (1992) Trophic interactions and direct physical effects control phytoplankton biomass and production in an estuary. Limnol. Oceanogr. 37, 946-955.

14. Phelps, H.L. (1994) The asiatic clam (Corbicula fluminea) invasion and system-level ecological change in the Potomac River Estuary near Washington, D.C. Estuar., 614-621.

15. Snelgrove, P., Blackburn, T.H., Hutchings, P.A., Alongi, D.M., Grassle, J.F., Hummel, H., King, G., Koike, I., Lambshead, P.J.D., Ramsing, N.B., Solis-Wiess, V., and Freckman, D. (1997) The importance of marine sediment biodiversity in ecosystem services. Ambio 26, 578-583.

16. Izsak, C. and Price, A.R.G. (2001) Measuring B-diversity using a taxonomic similarity index, and its relation to spatial scale. Mar. Ecol. Progr. Ser. 215, 69-77.

17. Price, A.R.G., Keeling, M.J., and O'Callaghan C.J. (1999) Ocean-scale patterns of "biodiversity" of Atlantic asteroids determined from taxonomic distinctness and other measures. Biol. J. Linn. Soc. 66, 187-203.

18. Izsak, C. Price, A.R.G., Hardy J.T., and Basson, P.W. Biodiversity of periphyton (diatoms) and echinoderms around a refinery effluent, and possible associations with stability. Aquat. Ecosyst. Health Man. in press.

19. des Clers, S. (1998) Sustainability of the Falklands Islands Loligo squid fishery. In Conservation of Biological Resources. Milner Gulland, E.J. and Mace, R., Eds. Blackwell Scientific, Oxford. pp. 225-241.

20. Barnes, R.S.K., and Hughes, R.N. (1982) An Introduction to Marine Ecology. Blackwell Scientific, Oxford.

21. Price, A.R.G. (1982) Distribution of penaeid shrimp larvae along the Arabian Gulf coast of Saudi Arabia. J. Nat. Hist. 16, 745-757.

22. McGlade, J.M., Price, A., Klaus, R., and Metuzals, K. (1997) Recovery plans for the North Sea ecosystem, with special reference to cod, haddock and plaice. WWF-UK, $33 \mathrm{pp}$.

23. McGlade, J.M. and Metuzals, K. (2000) Options for the reduction of by-catches of harbour porpoises (Phocoena phocoena) in the North Sea. In Effects of fishing on non-target species and habitats. Kaiser, M. and de Groot, V., Eds. Blackwell Scientific, Oxford. pp. 332-353.

24. Pauly, D., Christensen, V., Dalsgaard, J., Froese, R., and Torrest, F.Jr. (1998) Fishing down marine food webs. Science 279, 860-863.

25. Caddy, J.F. and Garibaldi, L. (2000) Apparent changes in the trophic composition of world marine harvests: the perspective from the FAO capture database. Ocean Coast. Man. 43, 615-655.

26. Jennings, S. and Kaiser, M.J. (1998) The Effects of Fishing on Marine Ecosystems. Adv. Mar. Biol. 34, 201352.

27. Goni, R. (2000) Fisheries effects on ecosystems. In Seas at the Millennium. Sheppard, C.R.C., Ed, Elsevier Science Ltd., Oxford. pp. 117-133.

28. McGlade, J.M. (1989) Integrated fisheries management models: understanding the limits to marine resource exploitation. Amer. Fish. Soc. Symp. 6, 139-165.

29. McGlade, J. (1995) Integrating social and economic factors into fisheries management in the European Union: an issue of governance. In Environmental Management: Review of 1994 and Future Trends. Vol. 2, Paper No. 15. Earll, B., Ed. Bob Earll, Candle Cottage, Kempley, Glos. , U.K. pp. 77-80.

30. Caddy, J.F. (1999) Fisheries management in the twenty-first century: will new paradigms apply? Rev. Fish Biol. Fisher. 9, 1-43.

31. Todd, E.C.D. (1994) The cost of marine diseases. In Global changes and emergence of infectious diseases. Wilson, M.E. et al., Eds. New York Academy of Sciences, New York. pp. 423-435.

32. Sherman, B.H. (2000) Marine ecosystem health as an expression of morbidity, mortality and disease events. In Seas at the Millennium. Sheppard, C.R.C., Ed. Elsevier Science Ltd., Oxford. pp. 211-234.

33. Rana, K.J. and Immink, A.J. (2000) Farming of aquatic organisms, particularly the Chinese and Thai Experience. In Seas at the Millennium. Sheppard, C.R.C., Ed. Elsevier Science Ltd., Oxford. pp. 165-167. [

34. Roth, E., Ackefors, H. et al. An intellectual injustice to aquaculture development: a response to the review article on "Effect of aquaculture on world fish supplies". Mar. Pollut. Bull. in press.

35. Seijo, J.C. and Caddy, J.F. (2000) Uncertainty in bio-economic reference points and indicators of marine fisheries. Mar. Freshw. Res. 51 (5), 477-483. 
36. Roberts, C.M. (1997) Ecological advice for the global fisheries crisis. TREE 12(1), 35-38.

37. Roberts, C.M. and Hawkins, J. (2000) Fully-protected marine reserives: a guide.World Wildlife Fund Endangered Seas Campaign., Washington, D.C., U.S. and Environment Department, University of York, York, U.K., 131 p.

38. Keckes, S. Possible co-operation between regional seas conventions and regional fishery bodies in the field of ecosystem-based management of fisheries. Annex 3. Regional Seas Conventions and Programmes. Report for United Nations Environment Programme and Food and Agriculture Organization in prep.

39. Price, A.R.G. and Maragos, J.E. (2000) The Marshall Islands. In Seas at the Millennium. Vol. 1. Sheppard, C.R.C., Ed. Elsevier Science Ltd, Oxford. pp. 773-789.

40. McGlade, J.M. (1999) Ecosystem analysis and the governance of natural resources. In Advanced Ecological Theory. McGlade, J.M., Ed. Blackwell Scientific, Oxford. pp. 309-341.

41. McGlade, J.M. (2001) Governance of fisheries. In Science and Integrated Coastal Zone Management. Bodungen, B., Ed. . Dahlem University Press, Berlin, chap. 15.

42. McGlade, J..M., Pauly, D., and Silvestre, G. (1996) Interdisciplinary scientific methodologies for the sustainable use and management of coastal resource systems. Final Report to CEC (Contract CTI *-CT930349), Brussels.

43. FAO (1995) Review of the state of the world fishery resources: marine fisheries. FAO Fish. Circ. No. 884. Food and Agriculture Organization, Rome.

44. Milner Gulland, E.J. and Mace, R., Eds. (1998) Biological Conservation and Sustainable Use. Blackwell Scientific, Oxford.

45. Roberts, C.M. and Hawkins, J. (1999) Extinction risk in the sea. TREE 14(6), 241-246.

46. Alverson, D.L., Freeborn, M.H., Murawski, S.A., and Pope, G. (1994) A global assessment of fisheries bycatch and discards. FAO Fish. Technical Paper No. 339. Food and Agriculture Organization, Rome.

47. Watson, M. and Ormond, R.F.G. (1994) Effect of an artisanal fishery on the fish and urchin populations of a Kenyan coral reef. Mar. Ecol. Progr. Ser. 109, 115-129.

48. Hall, M.A., Alverson, D.L., and Metuzals, K. (2000) Bycatch: problems and solutions. In Seas at the Millennium: An Environmental Evaluation. Sheppard, C.R.C., Ed. Elsevier Science, London.

49. Pauly, D., Christensen, V. (1995) Primary production required to sustain global fisheries. Nature 374, $255-157$.

50. Roberts, C.M. (1995) Effects of fishing on the ecosystem structure of coral reefs. Conserv. Biol. 9(5), 988-995.

51. Guard, M. and Masaiganah, M. (1997) Dynamiting fishing in southern Tanzania, geographical variation, intensity of use and possible solutions. Mar. Pollut. Bull. 34(10), 758-762.

52. Kaiser, M.J. (1998) Changes in megafaunal benthic communities in different habitats after trawling disturbance. Conserv. Biol. 12(6), 1230-1235.

53. Kaiser, M.J., Edwards, D.B., Armstrong, P.J., Radford, K, Lough, N.E.L., Flatt, R.P.,and Jones, H.D. (1998) Changes in megafaunal benthic communities in different habitats after trawling disturbance. ICES J. Marine Sci. 55(3), 353-361.

54. Eldey, M.T. and Law, R. (1988) Evolution of life histories and yields in experimental populations of Daphnia magna. Biol. J. Linn. Soc. 34, 309-326.

55. Law, R. (1991) Fishing in evolutionary waters. New Sci. 1758, 35-37.

56. Smith, P.J. (1994) Genetic diversity of marine fisheries resources: possible impacts of fishing. FAO Fish. Tech. Pap. No. 344, Food and Agriculture Organization, Rome. 53 pp.

57. FAO (1998) FAO Yearbook. Fishery Statistics, Capture Production, Vol. 82, 1996. FAO Fish. Ser. No 140/FAO Stat. Ser. No. 140. Food and Agriculture Organization, Rome. 678 pp.

This article should be referenced as follows:

Price, A.R.G. (2001) The marine food chain in relation to biodiversity. TheScientificWorld 1, 579-587.

\section{Handling Editor:}

Charles Sheppard, Principal Editor for Marine Systems - a domain of TheScientificWorld. 

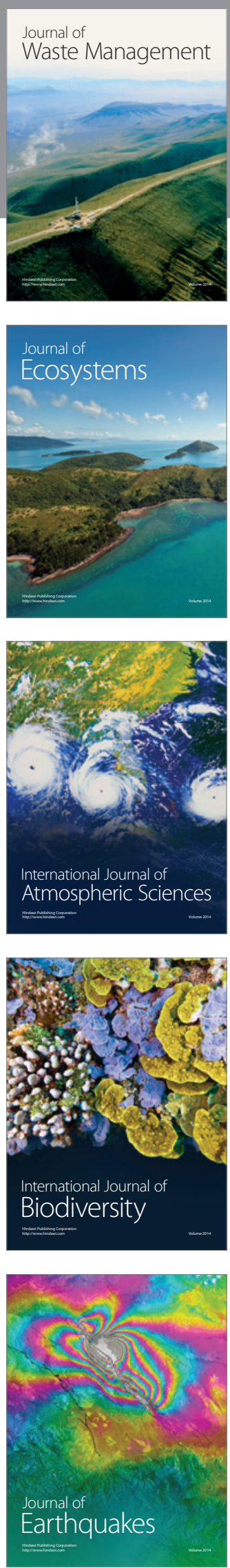
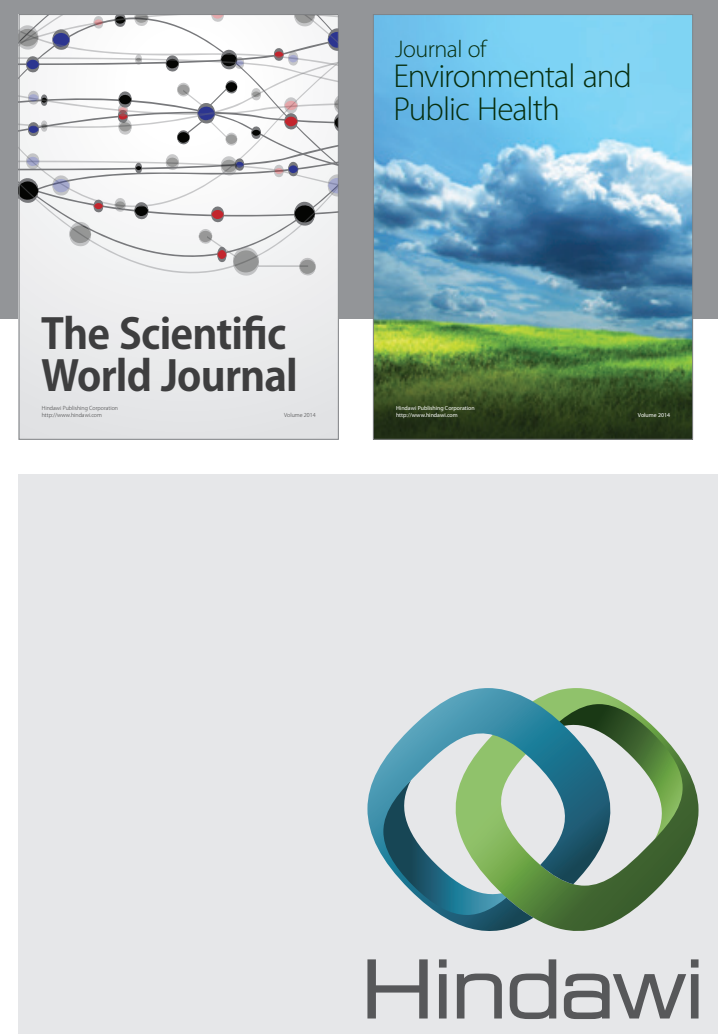

Submit your manuscripts at

http://www.hindawi.com
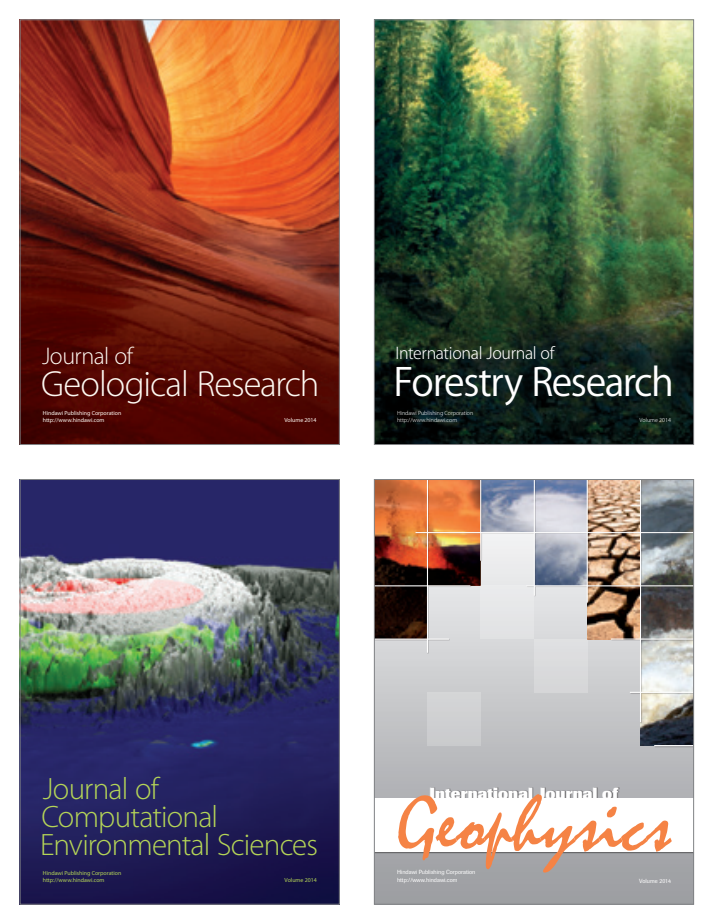
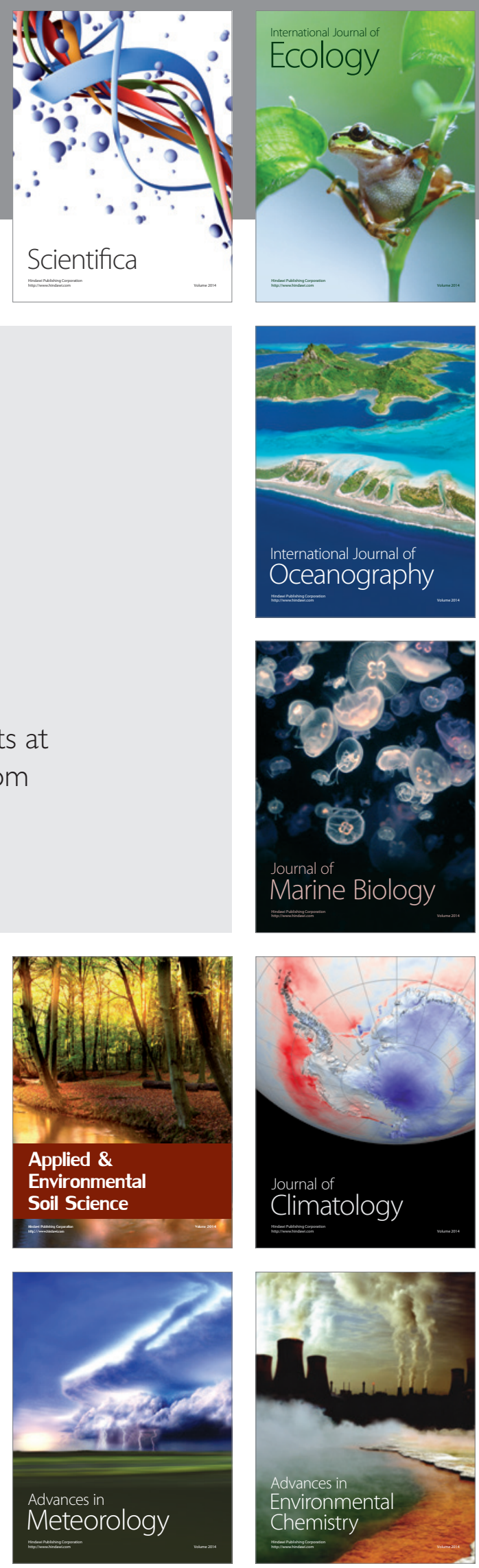